\title{
AKUNTANSI FORENSIK SEBAGAI STRATEGI PEMBERANTASAN KORUPSI SUAP
}

\author{
Bambang Arianto \\ Peneliti Research Center for Forensic Accounting \\ Sleman, Yogyakarta \\ ariantobambang2020@gmail.com
}

\begin{abstract}
This article aims to elaborate on the role of forensic accounting as a strategy to eradicate the criminal practice bribery in Indonesia. Forensic accounting can be used as a step to strengthen evidence by trying to collect various pieces of evidence through investigations into bribery corrupt practices. Forensic accounting is a scheme developed as a preventive, detective and persuasive strategy through the application of investigative audit procedures that are litigation for decision making in court. Thus, forensic accounting can be used as a strategy in an effort to eradicate the criminal practice of bribery corruption. This article uses the literature study method by elaborating various findings on the role of forensic accounting through a variety of literature both journals and newsletters. This article argues that the role of forensic accounting has made a positive contribution as a strategy in efforts to eradicate bribery corruption in Indonesia.
\end{abstract}

Keywords: Forensic Accounting, Removal of Corruption, Bribery and Corruption

\section{PENDAHULUAN}

Praktik korupsi suap di Indonesia masih terus terjadi meski kampanye anti korupsi terus digulirkan oleh Komisi Pemberantasan Korupsi (KPK). Bahkan diakhir tahun 2020, praktik pidana korupsi suap melibatkan Menteri Kelautan dan Perikanan, Eddy Prabowo dan Menteri Sosial Juliari Batubara. Kedua kasus tersebut mengonfirmasi bahwa kampanye anti korupsi ternyata belum cukup menjadi alat pencegah dari keinginan untuk melakukan tindak praktik pidana korupsi suap. Dengan begitu korupsi dapat dikatakan sebagai bayangan yang selalu mengikuti kemanapun subjek kekuasaan berada, sehingga dimanapun kekuasaan berada maka disanalah ada celah korupsi (Huntington, 1968).

Menurut catatan Indonesian Corruption Watch (ICW) terdapat 169 kasus korupsi selama periode semester satu tahun 2020. Hal ini berdasarkan pemantauan yang dilakukan ICW sejak 1 Januari hingga 30 Juni 2020. Dari 169 kasus korupsi yang disidik oleh penegak 
hukum, terdapat 139 kasus diantaranya merupakan kasus korupsi baru. Meski demikian, ICW mencatat tren penindakan kasus korupsi pada 2019 menurun dibandingkan tahun 2018 yakni dari 454 kasus yang ditangani menjadi 271 kasus. Penurunan tersebut dipengaruhi bergesernya prioritas pemerintah dalam memberantas korupsi yakni melalui upaya pencegahan (Kompas.com, 2020).

Bila ditelisik, praktik korupsi suap yang terjadi di Indonesia mayoritas terjadi dalam ranah politik yang notabene melibatkan para elit partai politik dan politisi di Indonesia. Dikarenakan tingginya biaya politik di Indonesia, sehingga membuat banyak elit partai politik berusaha mendapatkan pemasukan untuk biaya politik. Eksesnya elit politik seringkali melakukan praktik korupsi suap guna memenuhi biaya politik. Selain dalam konteks politik, praktik fraud (kecurangan) banyak terjadi dalam ranah keuangan dan perbankan yang cukup besar dan pernah terjadi di Indonesia. Dalam konteks ini definisi fraud (kecurangan) merupakan suatu pengertian secara umum dan mencakup beragam cara yang dapat digunakan untuk mendapatkan keuntungan dari orang lain melalui berbagai perbuatan yang tidak benar.

Tetapi, satu-satunya batasan dalam pengertian ini adalah sifat ketidakjujuran manusia (Albrecht et. al, 2012). Definisi lain mengenai fraud dipertegas oleh Association of Certified Fraud Examiner (ACFE) dalam Fraud Examiners Manual yang menjelaskan bahwa fraud (kecurangan) berkenaan dengan adanya keuntungan yang diperoleh seseorang dengan menghadirkan sesuatu yang tidak sesuai dengan keadaan yang sebenarnya. Dengan kata lain, di dalamnya termasuk unsur-unsur surprise atau tidak terduga, tipu daya, dan tidak jujur yang bisa merugikan orang lain.

Dalam dunia bisnis dan keuangan ada beberapa praktik fraud (kecurangan) yang cukup besar. Seperti; kasus Malinda Dee yang terbukti membobol dana nasabah Citibank pada tahun 2011. Malinda melakukan 117 transaksi pemindahan dana tanpa izin dan sepengetahuan pemilik rekening. Total dana yang ditarik oleh Malinda mencapai Rp 46,1 miliar lebih. Selanjutnya ada kasus teller Bank Rakyat Indonesia (BRI) pada Januari 2019 yang menilap uang puluhan nasabah BRI di Makassar hingga lebih dari Rp 2,3 miliar.

Kemudian ada Maria Pauline Lumowa yang membobol Bank BNI 46 hingga mencapai Rp 1,7 triliun. Melalui pinjaman BNI yang diberikan kepada PT Gramarindo Group milik Maria Pauline Lumowa dan Adrian Waworuntu. Selain itu ada kasus pembobolan BNI Rp 65 
Miliar oleh Iman Patriuddin dan Ruzi Andi Harahap. Lebih lanjut, ada kasus Kepala Cabang Maybank Cipulir yang diduga menilap uang tabungan Rp 22 miliar milik atlet eSport, Winda Lunardi. Tersangka memanfaatkan jabatan untuk menawarkan pembuatan rekening berjangka kepada korban, tetapi ternyata rekening tersebut dipalsukan (kompas.com, 2020).

Dengan banyaknya praktik fraud (kecurangan) baik dalam ranah politik maupun bisnis, membuat diperlukan strategi pemberantasan yang lebih sistematis. Salah satu langkah terbaik dalam upaya pemberantasan korupsi suap adalah dengan menggunakan skema audit forensik, yakni penggunaan para profesional akuntan forensik. Hal itu tanpa alasan, sebab profesi akuntansi forensik sebenarnya telah terdapat dalam Kitab Undang-Undang Hukum Acara Pidana (KUHAP) Pasal 179 Ayat 1. Bahkan beberapa studi mengatakan bahwa ilmu akuntansi forensik terbukti dapat menekan praktik fraud (kecurangan) (Chi-Chi dan Ebimobowei 2012; Alabdullah et. Al, 2014; Temitope, 2014).

Perlu diketahui bahwa akuntansi forensik berasal dari dua kata, akuntansi dan forensik. Kata forensik berasal dari bahasa latin "forensik" yang berarti mengumpulkan fakta atau bukti yang digunakan untuk mendukung sebuah argumentasi dalam proses pengadilan. Dengan demikian profesi akuntansi forensik bertujuan mendeteksi kecurangan (fraud) pada organisasi sesuai dengan permintaan. Dengan kata lain, bahwa ruang lingkup akuntansi forensik terdiri atas akuntansi, hukum, dan auditing (Tuanakotta, 2010). Dengan kata lain, akuntansi forensik merupakan suatu skema yang dikembangkan sebagai strategi deteksi melalui tindakan persuasif dan preventif dengan penerapan prosedur audit investigasi yang bersifat ligitasi untuk menghasilkan berbagai temuan dan alat bukti adanya indikasi fraud (kecurangan). Sehingga berbagai temuan dan alat bukti tersebut dapat digunakan dalam proses pengambilan keputusan di pengadilan (Arianto, 2020).

Dalam konteks Indonesia, profesi akuntansi forensik telah hadir sekitar awal 2000-an, saat terbitnya UU No. 28 Tahun 1999 tentang Pemerintahan yang Bebas Korupsi Kolusi dan Nepotisme, UU No. 31 Tahun 1999 tentang Tindak Pidana Korupsi, dan UU No. 17 Tahun 2003 Tentang Keuangan Negara. Awalnya profesi akuntansi forensik seringkali digunakan oleh lembaga pemerintah Amerika Serikat, seperti CIA, FBI dan IRS untuk mengungkapkan berbagai kasus penipuan. Tetapi seiring waktu akuntansi forensik kemudian berkembang disejumlah 
negara. Sedangkan dalam konteks Indonesia, akuntansi forensik sudah dikenal sejak tahun 1997, ketika PwC berhasil membongkar kasus PT Bank Bali Tbk yang menjerat beberapa pejabat dan pengusaha Indonesia (news.ddtc.co.id, 2020).

Lebih lanjut, beberapa studi menjelaskan dalam pelaksanaannya audit forensik membutuhkan berbagai alat bukti yang relevan, otentik dan tepat dalam proses pencarian dan pengumpulan bukti. Dikarenakan, karakter dari audit forensik, bersifat proaktif dan reaktif. Dalam konteks ini, proaktif adalah audit forensik digunakan untuk mendeteksi kemungkinan-kemungkinan resiko terjadinya fraud (kecurangan). Sedangkan reaktif artinya audit forensik akan dilakukan ketika ada indikasi (bukti) awal terjadinya fraud (kecurangan) (Fakie, 1999). Dengan demikian, audit forensik dapat berperan dalam mendeteksi fraud (Enofe, et. al, 2015; Syahputra \& Urumsah 2018; Mamahit \& Urumsah, 2018; Claudia 2018; Wiratmaja, 2008; Lediastuti, 2014).

Selain itu dalam akuntansi forensik dikenal proses investigasi dalam pengumpulan alat bukti. Audit investigasi merupakan suatu pemeriksaan yang bertujuan untuk mengidentifikasi dan mengungkap kecurangan atau kejahatan dengan menggunakan pendekatan, prosedur dan teknik-teknik yang umumnya digunakan dalam suatu kejahatan (Rahmayani, et. al. 2014). Lebih lanjut dalam audit investigasi digunakan beberapa metode seperti audit investigasi dengan teknik audit, audit investigasi dengan teknik perpajakan, follow the money, audit investigasi dengan menganalisis unsur perbuatan melawan hukum, investigasi pengadaaan, dan computer forensics (Tuanakotta, 2017).

Lebih lanjut, dalam mengelaborasi terjadinya praktik korupsi suap di Indonesia para akuntan forensik merujuk pada landasan teori fraud (kecurangan). Meski begitu, seiring meningkatnya praktik kecurangan (fraud) di berbagai sektor telah membuat teori fraud (kecurangan) mengalami perkembangan. Hal ini yang melahirkan teori fraud pentagon. Teori ini dikembangkan oleh Crowe Horwart pada tahun 2012. Teori ini merupakan pengembangan dari teori-teori sebelumnya. Seperti Fraud triangle oleh Cressey pada tahun 1953 dan fraud diamond yang dikembangkan oleh Wolfe dan Hermanson pada tahun 2004. Dalam teori fraud pentagon ada beberapa penambahan elemen-elemen yang sangat berpengaruh terhadap kecurangan (fraud). Diketahui bahwa praktik kecurangan (fraud) dalam hal ini korupsi suap berdasarkan beberapa hal diantaranya; 
(peluang), pressure (tekanan), rasionalization (rasionalisasi), competence (kompetensi) dan arogance (arogansi) (Boyle, et.al, 2015). Selain itu melalui teori fraud pentagon, akuntansi forensik dapat mengetahui latar belakang dibalik angka-angka terjadinya berbagai bentuk kecurangan (fraud). Sehingga kemudian akuntan forensik seringkali memberikan dua jenis jasa, yaitu jasa penyelidikan yang mengarah pada proses pemeriksaan sesuatu yang tidak biasa (red flag) dan jasa ligitasi yang dikhususkan untuk ranah pengadilan.

Menariknya, seiring perkembangannya zaman, akuntansi forensik banyak mendapatkan respon positif. Apalagi, Komisi Pemberantasan Korupsi (KPK) telah membentuk unit khusus akuntansi forensik yang bertugas mengawasi aliran dana sektor keuangan sekaligus memperkuat kinerja lembaga dalam memberantas korupsi. Meski begitu faktanya masih banyak penegak hukum di Indonesia yang belum memanfaatkan keahlian akuntansi forensik dalam mencari alat bukti dalam kejahatan keuangan atau fraud (Antaranews.com, 2000). Hal itu disebabkan profesi akuntansi forensik masih menjadi profesi yang masih langka di Indonesia.

Pada akhirnya artikel ini fokus pada peran akuntansi forensik sebagai suatu strategi pemberantasan praktik korupsi suBeberapa penelitian telah mengelaborasi peran akuntansi forensik dalam mendeteksi fraud (kecurangan) dan praktik korupsi dari berbagai negara (Islam, et. al, 2011; Alabdullah, et. al, 2014; Ocansey, 2017; Okoye \& Gbegi, 2013; Okpako \& Atube, 2013). Sedangkan peran akuntansi forensik dalam pemberantasan korupsi dalam konteks Indonesia masih sedikit ditemukan (Wiratmaja, 1998). Sehingga perbedaan penelitian ini dengan sebelumnya, terletak pada peran akuntansi forensik sebagai strategi pemberantasan praktik korupsi suap konteks ke-Indonesia-an. Dengan demikian, artikel ini mengajak pada sebuah pertanyaan, bagaimana peran akuntansi forensik sebagai strategi pemberantasan korupsi suap di Indonesia? Batasan dalam artikel ini hanya seputar peran dan implikasi akuntansi forensik sebagai suatu strategi pemberantasan praktik pidana korupsi suap.

\section{METODE PENELITIAN}

Artikel ini menggunakan metode kualitatif dengan pendekatan studi kepustakaan yakni dengan mengamati dan menganalisis semua informasi mengenai topik penelitian. Metode ini kemudian dikombinasikan dengan penelitian terdahulu agar dapat menjelaskan 
fenomena yang akan terjadi (Mamahit \& Urumsah, 2018). Ada empat langkah yang akan dilakukan dalam mengelaborasi topik penelitian dengan pendekatan studi kepustakaan yakni; Pertama, peneliti mengamati dan menganalisis berbagai informasi yang terkait dengan topik penelitian. Terutama teori yang akan digunakan dengan berbagai penelitian terdahulu. Kedua, mengumpulkan berbagai literatur yang relevan dengan topik penelitian agar bisa menjelaskan fenomena yang terjadi. Berbagai literatur yang dikumpulkan untuk dijadikan rujukan berupa jurnal ilmiah, makalah penelitian, serta informasi pendukung lainnya. Tujuannya untuk memadukan hasil temuan bertema sama sebagai kajian pendahuluan (preliminary studies) dengan kajian kekinian (Zed, 2008). Dengan demikian verifikasi atas kajian terdahulu bisa menemukan unsur kebaruan (novelty) dalam penelitian selanjutnya. Ketiga, mengidentifikasi berbagai variabel yang relevan dengan topik penelitian, Variabelvariabel ini dapat memberi ruang lingkup penelitian baru dan dapat membantu mengidentifikasi berbagai variabel yang terkait dengan penelitian. Terakhir, membangun kerangka kerja. Dalam hal ini peneliti mulai membangun kerangka kerja yang diperlukan dengan menggunakan variabel dari artikel ilmiah dan materi terkait lainnya. Sehingga tahapan ini akan terbentuk sebuah kerangka pengetahuan dan informasi yang lebih relevan dengan topik penelitian.

\section{PEMBAHASAN}

\section{Fenomena Praktik Pidana Korupsi Suap}

Artikel ini akan mengelaborasi beberapa praktik pidana korupsi suap yang terjadi di Indonesia. Dimulai dari praktik pidana korupsi suap yang dilakukan oleh Menteri Pemuda dan Olah Raga Imam Nahrawi. Dalam kasus ini Imam Nahrawi terbukti bersalah menerima suap pencairan dana hibah dari Kemenpora ke Komite Olahraga Nasional Indonesia, serta kasus gratifikasi senilai Rp 8,6 miliar selama menjabat. Jaksa Komisi Pemberantasan Korupsi menilai Imam Nahrawi terbukti menerima suap senilai $\mathrm{Rp}$ 11,5 miliar untuk pencarian dana hibah dari Kementerian Pemuda dan Olahraga ke Komite Olahraga Nasional Indonesia. Praktik suap ini diterima melalui asisten pribadinya, Miftahul Ulum yang kemudian dituntut 9 tahun penjara. Tindakan suap diberikan untuk mempercepat proses persetujuan dan pencairan bantuan dana hibah yang diajukan oleh KONI Pusat kepada Kemenpora tahun anggaran 2018. Gratifikasi itu berasal dari Sekretaris 
Jenderal KONI Ending Fuad Hamidy sehubungan dengan program Indonesia Emas. Selain hukuman penjara dan denda, hukuman tambahan kepada terdakwa Imam Nahrawi berupa pencabutan hak untuk dipilih dalam jabatan publik selama empat tahun terhitung setelah terdakwa selesai menjalani hukuman pidana pokok (Tempo.co, 2020).

Sedangkan praktik fraud (kecurangan) diluar ranah politik adalah yang menimpa PT Maybank Indonesia Tbk. Praktik fraud (kecurangan) ini terkuak ketika tabungan Atlet eSport Winda Lunardi dan ibunya, Floleta sebesar Rp 20 miliar di korupsi oleh oknum yang merupakan Kepala Cabang Maybank. Selain itu ada pula kasus dengan nama asli Inong Malinda yang terbukti membobol dana nasabah di bank tempatnya bekerja, Citibank pada tahun 2011. Menurut Jaksa, Malinda telah melakukan 117 transaksi pemindahan dana tanpa izin dan sepengetahuan pemilik rekening. Dengan total dana yang di korupsi oleh Malinda mencapai Rp 46,1 miliar lebih. Transaksi tersebut terdiri atas 64 transaksi dalam rupiah, dengan nilai $\mathrm{Rp}$ 27.369.065.650 dan 53 transaksi dalam dolar AS dengan nilai US\$ 2.082.427. Pada 3 Maret 2012, Malinda Dee divonis 8 tahun penjara dan denda $\mathrm{Rp} 10$ miliar subsider 3 bulan kurungan dalam kasus tindak pidana perbankan pencucian uang (Detik.com, 2020).

Kasus fraud (kecurangan) lainnya adalah pembobolan rekening atas nama Anggita Wahyuningtyas dengan jumlah dana yang cukup besar yakni di atas Rp50 juta. Pembobolan itu berawal dari adanya panggilan telepon dari pihak penipu yang seolah-olah bertindak sebagai call-center pada 7 September 2020. Isi dari panggilan telepon tersebut menyebutkan adanya pembaruan sistem dan adanya penggantian kartu ATM. Korban memberitahukan data diri. Hanya dalam hitungan menit, pelaku sudah menyedot uang milik korban dan kemudian mentransfernya ke rekening lain atas nama Lutfi Putri Mardiana. Setelah dilacak ternyata pemilik rekening tersebut tinggal di Lampung dan mengaku rekeningnya sedang di-hack oleh orang yang tidak dikenal. Pada hari yang sama, uang hasil curian dari akun rekening Jenius milik Anggita sudah dipindahkan ke dua rekening lain (finansial.bisnis.com, 2020).

$$
\text { Berbagai praktik fraud }
$$
(kecurangan) yang meliputi korupsi suap dan lain sebagainya ternyata semakin canggih sehingga membuat diperlukan skema khusus untuk dapat memberantas praktik tersebut secara sistematis. Dalam hal ini diperlukan skema dari profesi akuntansi forensik yaitu audit forensik. Sebab, skema akuntansi forensik memiliki 
berbagai keunggulan dalam pengumpulan alat bukti yang dapat ikut membantu proses pemberantasan korupsi suap. Selain itu skema akuntansi forensik banyak digunakan oleh berbagai pihak untuk pemberantasan korupsi. Seperti, Komisi Pemberantasan Korupsi (KPK) yang telah menggunakan akuntansi forensik dalam pemberantasan korupsi. Hal itu dibuktikan dari pembentukan unit forensic accounting (unit akuntansi forensik) oleh KPK. Unit ini bertujuan untuk meningkatkan kinerja dalam meneliti sejumlah kasus korupsi terutama yang menjerat korporasi seperti perusahaan BUMN. Selain itu unit akuntansi forensik bertugas mengawasi dan meneliti keluar masuk keuangan dari negara dan perusahaan. Dengan demikian unit ini dapat membantu pemulihan aset yang berkaitan dengan sejumlah kasus korupsi yang ditangani oleh KPK (cnnindonesia.com, 2019).

Sedangkan dalam beberapa kasus korupsi yang terjadi di Indonesia, banyak pihak menginginkan dibentuknya tim audit forensik untuk mengungkap berbagai skandal korupsi suap. Jadi tidak heran bila kemudian banyak pihak meminta dilakukan audit forensik terhadap berbagai praktik tindak pidana korupsi suap seperti pada skandal Bank Century. Menurut anggota tim pengawas (Timwas) Bank
Century, Bambang Soesatyo tim audit forensik dari Badan Pemeriksa Keuangan (BPK) di harapkan dapat mengungkap mega skandal yang telah merugikan keuangan negara sebesar Rp 6,7 triliun.

Apalagi hasil audit forensik BPK menyatakan ada indikasi penyimpangan dan pelanggaran dalam proses pencairan dana talangan bagi Bank Century. Hasilnya dari audit forensik tersebut nanti akan diketahui ke rekening siapa saja uang Bank Century itu mengalir. Sebab semenjak proses audit forensik berlangsung, BPK telah menemukan indikasi aliran dana Bank Century yang digunakan oleh salah satu pasangan Capres-Cawapres 2009 (Jpnn.com, 2011). Dengan penerapan metode audit forensik oleh Badan Pemeriksa Keuangan (BPK) tentang aliran dana Bank Century tentulah dapat dijadikan sebagai alat bukti hukum (Kompas.com, 2011).

Lebih lanjut dalam beberapa kasus fraud (kecurangan) lainnya, Kejaksaan Agung telah melakukan audit forensik dalam proses investigasi kasus dugaan korupsi pada PT Asuransi Jiwasraya (Persero). Bahkan para penyidik Kejagung telah menggandakan perangkat teknologi informasi dari hasil penggeledahan. Proses penggandaan data dari perangkat milik dua tersangka, yaitu Direktur Utama PT Hanson International Tbk Benny 
Tjokrosaputro dan mantan Kepala Divisi Investasi dan Keuangan PT Asuransi Jiwasraya Syahmirwan. Selain itu, tim audit forensik juga melakukan kloning atau audit forensik terhadap komputer yang digunakan dalam transaksi tersebut. Dengan demikian yang dilakukan dalam proses audit forensik ini untuk memastikan dimana saja praktik fraud (kecurangan) yang sudah mengorbankan jutaan nasabah pensiunan TNI dan Polri tersebut (Kompas.com, 2020).

\section{Akuntansi Forensik dan Kecurangan (Fraud).}

Perlu diketahui bahwa hasil audit dari akuntansi forensik dapat dijadikan alat bukti dalam pengadilan sejak abad ke-18 di Kanada. Tepatnya dalam kasus Meyer vs Sefton pada tahun 1817. Kasus ini diketahui merupakan kasus pertama seorang akuntan forensik dimintai keterangan sebagai saksi ahli di pengadilan. Dengan demikian, akuntansi forensik dapat dikatakan sebagai penggunaan keahlian di bidang audit dan akuntansi yang dipadukan dengan kemampuan investigatif untuk memecahkan suatu masalah keuangan, termasuk mendeteksi berbagai bentuk kecurangan. Sehingga akuntansi forensik berperan tidak hanya untuk mengungkapkan fakta-fakta yang terjadi dan kemudian dijadikan dasar maupun alat bukti dalam berbagai bentuk kejahatan. Akan tetapi akuntansi forensik berperan menelurusi hingga sejauh mana titik temu tersangka yang menjadi pelaku kecurangan dan menghadapkannya ke pengadilan dengan bukti-bukti yang diperolah selama penerapan akuntansi forensik.

Selain itu, seiring dengan perkembangan inovasi teknologi digital membuat celah kecurangan semakin berkembang, yang membuat diperlukan strategi antisipasi. Meski demikian, dalam strategi pemberantasan praktik korupsi suap kedepan harus diperlukan pula keahlian tambahan seperti cyber security dan digital forensic dalam pengembangan profesi akuntansi forensik. Dikarenakan kemajuan teknologi informasi dan digitalisasi akuntansi membuat bentuk kecurangan (fraud) akan semakin meningkat. Artinya, ketika seseorang melakukan fraud (kecurangan) melalui teknologi informasi, maka harus di deteksi pula melalui penerapan teknologi informasi. Identifikasi tersebut semakin mengkonfirmasi bahwa akuntansi forensik sangat tepat digunakan untuk mendukung strategi pemberantasan korupsi suap. Apalagi, dalam akuntansi forensik terdapat sifat penelusuran yang dikenal dengan audit investigatif. Sehingga hasil temuan 
akuntan forensik kemudian dapat dijadikan sebagai alat bukti di pengadilan.

Sedangkan dalam konteks bisnis untuk membuktikan fraud (kecurangan) jelas membutuhkan suatu analisis dan investigasi laporan perusahaan dan ujung dari suatu proses investigasi adalah pengadilan (hukumonline,com, 2019).

Oleh karena itu, akuntansi forensik memiliki peran penting untuk mengungkapkan fakta-fakta yang terjadi dan dijadikan sebagai dasar alat bukti dalam berbagai bentuk kecurangan (fraud).

Termasuk untuk mengetahui motif dibalik terjadinya praktik kecurangan (fraud) tersebut. Sedangkan pada sektor swasta akuntansi forensik dapat digunakan untuk mengatasi berbagai kasus kejahatan keuangan seperti penggelapan, kekeliruan fakta keuangan, pembakaran nirlaba, penipuan bank, suap dan penyuapan komersial, penipuan komputer, penggelapan pajak dan lain sebagainya.

\section{Peran Strategis Akuntansi Forensik}

Lebih lanjut beberapa tahapan akuntansi forensik dalam mendeteksi hingga mengungkap praktik fraud (kecurangan) meliputi; (1) Identifikasi masalah, (2) Pembicaraan dengan klien. (3) Pemeriksaan pendahuluan, Pengembangan rencana pemeriksaan, (5) Pemeriksaan lanjutan, (6) Penyusunan laporan, (7). Pada tahap ini, auditor forensik akan mengeluarkan semacam laporan audit forensik. Sedangkan untuk keahlian khusus seorang akuntan forensik yang paling utama adalah keahlian untuk audit. Sebab keahlian audit di nilai sebagai keahlian terpenting sebelum atau pengetahuan dasar sebelum menjadi akuntan forensik. Dengan demikian, urutan untuk keahlian khusus akuntan forensik yaitu, keahlian audit dengan 87.54 persen, kemampuan investigasi dengan 66.78 persen, intuisi investigasi dengan 59.17 persen, kritis dan pemikir strategis dengan 57.44 persen dan mengintegrasi hasil analisa dan penemuan dengan 40.48 persen. Selain itu seorang akuntan forensik perlu memahami berbagai kelimuan tambahan, seperti teknologi informasi, psikologi, komunikasi dan hukum.

Lebih lanjut, dengan semakin beragamanya modus operandi praktik fraud (kecurangan) membuat diperlukan strategi khusus dalam proses pemberantasan praktik pidana korupsi suap. Dengan demikian pemberantasan praktik korupsi suap meliputi beberapa tahapan strategi, yaitu detektif, represif dan preventif. Pertama, strategi detektif. Dalam proses pemberantasan korupsi suap diperlukan strategi detektif untuk mengidentifikasi terjadinya perbuatan korupsi suap. Dalam hal ini ada beberapa 
langkah taktis sebagai bagian strategi detektif diantaranya yaitu memperbaiki saluran sistem dan tindak lanjut atas pengaduan dari masyarakat.

Salah satu saluran untuk mengumpulkan alat bukti adalah dengan saluran pelaporan melalui whistleblowing system. Dalam hal ini whistleblowing merupakan sebuah sistem saluran yang dirancang sedemikian rupa agar bisa mengenal lebih dekat berbagai kriteria kecurangan yang dilaporkan. Dengan pemanfaatan sistem whistleblowing yang sistematis dan terstruktur tentu bisa mendorong setiap individu agar berani secara diam-diam melaporkan berbagai pelanggaran, kecurangan, aktivitas yang tidak jujur, praktik penyuapan atau kecurangan lain yang dilakukan oleh manajemen maupun oknum tertentu.

Dalam konteks ini whistleblowing merupakan sebuah sistem saluran yang dirancang sedemikian rupa agar bisa mengenal lebih dekat berbagai kriteria kecurangan (fraud) yang dilaporkan. Pelaporan dalam whistleblowing harus memuat prinsip dasar yang meliputi $4 \mathrm{~W}+$ 1H. Pengertian lain mengenai whistleblowing merupakan sebuah pengungkapan oleh anggota organisasi tentang praktik ilegal, tidak bermoral atau tidak sah dibawah kendali atasan, kepada anggota atau organisasi yang dapat mempengaruhi tindakan (Near \& Miceli, 1985). Dengan demikian skema ini dibentuk sebagai langkah taktis untuk menekan dan mencegah terjadinya berbagai pelanggaran dan kecurangan dalam internal perusahaan atau organisasi. Dengan begitu, sistem ini akan memudahkan bagi karyawan maupun pihak diluar perusahaan untuk bisa melaporkan berbagai kecurangan yang terjadi dalam internal perusahaan.

Tujuan lain dari whistleblowing adalah menekan tindak kecurangan yang dapat merugikan perusahaan. Akan tetapi sistem dan skema yang dibangun ini akan disesuaikan dengan budaya yang ada diperusahaan setempat, sehingga akan bisa memberikan banyak manfaat bagi perusahaan dalam pelaksanaan corporate governance (Semendawai, 2011). Dengan demikian penerapan whistleblowing telah terbukti dapat mendeteksi terjadinya praktik fraud (kecurangan) karena dapat mengumpulkan berbagai alat bukti, data dan informasi (Enofe et. al, 2015; Mamahit \& Urumsah; Daurrohmah \& Urumsah, 2018).

Lebih lanjut dalam strategi detektif diberlakukan kewajiban pelaporan transaksi keuangan tertentu baik kekayaan pribadi pemegang jabatan dan fungsi publik. Deteksi awal ini ditujukan agar bisa mendeteksi terjadinya fraud 
(kecurangan). Oleh sebab itu diperlukan partisipasi aktif masyarakat untuk dapat ikut dalam gerakan pemberantasan korupsi dan anti pencucian uang. Kedua, strategi represif. Pemberantasan korupsi suap memerlukan strategi represif yang ditujukan untuk menangani atau memproses perbuatan korupsi sesuai dengan peraturan perundang-undangan yang berlaku. Strategi represif dapat dilakukan seperti melalui pembentukan lembaga anti rasuah atau komisi anti korupsi seperti Komisi Pemberantasan Korupsi. Lebih lanjut proses penyidikan, penuntutan, peradilan, dan penghukuman koruptor besar (Catch some big fishes). Dalam hal ini peran akuntansi forensik sangat penting dalam membantu penerapan strategi represif. Akan tetapi, strategi represif lainnya bisa melalui penentuan jenis atau kelompok-kelompok korupsi yang diprioritaskan untuk diberantas termasuk dengan mempublikasikan beberapa kasus-kasus tindak pidana korupsi beserta analisisnya.

Ketiga, strategi preventif, yaitu upaya pencegahan korupsi yang diarahkan untuk meminimalkan penyebab dan peluang untuk melakukan praktik korupsi. Dalam strategi ini diarahkan untuk mendeteksi terjadinya kasus korupsi dengan cepat, tepat dengan biaya murah, sehingga dapat segera ditindaklanjuti.
Upaya represif adalah usaha yang diarahkan agar setiap perbuatan korupsi yang telah diidentifikasi dapat diproses secara cepat, tepat, dengan biaya murah, sehingga para pelakunya dapat segera diberikan sanksi sesuai peraturan perundangan yang berlaku. Dalam strategi preventif ini peran dari akuntansi forensik memiliki andil yang cukup besar. Sebab merujuk teori fraud pentagon, bahwa kesempatan atau peluang menjadi salah satu faktor terjadinya fraud (kecurangan). Peluang ini seringkali menjadi salah satu elemen utama bagi seseorang untuk melakukan praktik fraud (kecurangan).

Berbagai identifikasi tersebut semakin mengonfirmasi bahwa peran penting dari akuntansi forensik sangat menentukan keberhasilan upaya pemberantasan praktik korupsi suap. Dikarenakan akuntansi forensik memiliki skema yang baik dalam pengumpulan alat bukti otentik yang akan diajukan dihadapan pengadilan. Dengan begitu kedepan sudah dapat dipastikan profesi akuntansi forensik akan memiliki peran penting dan strategis dalam upaya pemberantasan korupsi suap dan tentunya meminimalisir praktik fraud (kecurangan) di Indonesia. 


\section{KESIMPULAN}

Praktik kecurangan (fraud) dalam hal ini korupsi suap masih terus terjadi baik dalam ranah politik maupun bisnis, meskipun kampanye anti korupsi terus digulirkan. Hal itu menjadi pertanda bahwa upaya pencegahan dan pemberantasan korupsi harus terus diperkuat. Dalam konteks pemberantasan korupsi ada tiga strategi pencegahan yaitu, detektif, represif dan preventif. Ketiga strategi ini dapat menjadi langkah penting dalam pemberantasan praktik korupsi suap. Meski demikian, peran dari profesi akuntansi forensik sangat mendukung penerapan ketiga strategi tersebut terutama dalam proses pemberantasan korupsi suap. Dikarenakan akuntansi forensik merupakan proses penunjukan khusus dalam upaya pengumpulan alat bukti melalui audit investigasi dalam suatu tindak pidana korupsi suap. Pemberantasan praktik pidana korupsi suap dimulai dengan penerapan strategi detektif yang bertujuan mengidentifikasi terjadinya perbuatan korupsi suap. Proses deteksi ini adalah dengan membangun saluran sistem dan langkah tindak lanjut atas pengaduan dari masyarakat. Dalam akuntansi forensik, saluran pelaporan ini dapat dibangun melalui sistem whistleblowing. Selain itu penerapan sistem whistleblowing sebagai saluran pelaporan dapat menarik partisipasi publik untuk melaporkan berbagai bentuk kecurangan yang terselubung.

Lebih lanjut, akuntansi forensik mendukung dalam proses penerapan strategi represif. Strategi ini ditujukan untuk memproses segala perbuatan korupsi suap sesuai dengan peraturan perundangundangan yang berlaku. Akuntansi forensik dapat digunakan dalam bentuk pengumpulan alat bukti yang didahului oleh proses audit investigasi. Terakhir strategi preventif, yaitu upaya pencegahan korupsi yang diarahkan untuk meminimalkan penyebab terjadinya praktik tindak pidana korupsi suap. Dalam strategi ini diarahkan untuk mendeteksi terjadinya praktik korupsi suap dengan sistematis dan cepat. Penerapan akuntansi forensik dalam strategi preventif ditujukan untuk mengetahui penyebab terjadinya praktik korupsi suap.

Akhirnya, artikel ini menyimpulkan bahwa akuntansi forensik sangat berkontribusi positif dalam mendukung proses pemberantasan korupsi suap baik strategi preventif, detektif dan represif. Sebab, akuntansi forensik dapat mengetahui latar belakang dari terjadinya praktik korupsi suap dan fraud (kecurangan) diberbagai sektor. Sehingga kemudian akan diketahui secara komprehensif apa saja penyebab di balik 
kecurangan (fraud) keuangan yang telah terjadi. Dengan begitu, akuntansi forensik sangat memiliki peran strategi dalam pemberantasan praktik korupsi suap.

\section{DAFTAR PUSTAKA}

ACFE, Inc. (2018). Survai Fraud Indonesia 2016. Association of Certified Fraud Examiners Indonesia Chapter.

Albrecht, S.W., Albrecht, C.O., Albrecht, C.C., \& Zimbelman, M.F. (2012). Fraud Examination (4th Edition). USA : South - Western.

Alabdullah, T. T. Y., Alfadhl, M. M. A., Yahya, S., \& Rabi, A. M. A. (2014). The role of forensic accounting in reducing financial corruption: A study in Iraq. International Journal of Business and Management, 9(1), 26.

Arianto, B. (2020). Akuntansi Forensik dan Fenomena Korupsi Politik. Journal of Social Politics and Governance, 2, (1), 47-62

Bologna G. \& Robert. (1995). Fraud Auditing and Forensic Accounting, Tool and Techniques, 2th. Edition. New York : Jhon Wiley.

Boyle, D. M., DeZoort, F. T., \& Hermanson, D. R. (2015). The effect of alternative fraud model use on auditors' fraud risk judgments. Journal of Accounting and Public Policy, 34(6), 578-596.

Cnnindonesia.com. (2019). KPK bentuk unit akuntansi forensic untuk awasi aliran uang. (Online) https://www.cnnindonesia.com/nasio nal/20190807183404-12-

419290/kpk-bentuk-unit-akuntansiforensik-untuk-awasi-aliran-uang diakses 11 November 2020

(2020). BPK Temukan 5480

Masalah Berpotensi Rugikan Negara Rp 715 Triliun. (Online). https://www.cnnindonesia.com/ekon omi/20200505162301-532-

500345/bpk-temukan-5480-masalahberpotensi-rugikan-negara-rp715-t

Claudia, G. (2018). Akuntansi Forensik untuk Bedah Kasus Korupsi. JEMAP : Jurnal Ekonomi, Manajemen, Akuntansi dan Perpajakan. Vol. 1, (1), 95.

Chi-chi, OA \& Ebimobowei, A (2012). Fraudulent Activities and Forensic Accounting Services of Banks in Port Harcourt, Nigeria. Asian Journal of Business Management. Vol 4, No 2 ,

Detik.com. (2020). Deretan kasus pembobolan Bank di Indonesia yang bikin heboh. (Online). https://finance.detik.com/moneter/d5246157/deretan-kasus-pembobolanbank-di-indonesia-yang-bikin-heboh diakses 11 November 2020

Daurrohmah, E. W., \& Urumsah, D (2018). Efektivitas Audit Forensik dalam Mendeteksi Suap dengan Dukungan Whistleblowing. Tesis. Universitas Islam Indonesia.

News.ddtc.co. (2020). Memperkuat Pembuktian dengan Akuntansi Forensik. (Online). https://news.ddtc.co.id/memperkuatpembuktian-dengan-akuntansiforensik-25773 diakses 13 November 2020.

Enofe, A., Julius, O., \& Ogbeide, O. (2015). The Role of Forensic Accounting in Combating Financial Crimes. Research Journal of Finance and Accounting, 6(18), 191-199.

Fakie, S. (1999). The role of the Office of the Auditor-General in South Africa. In 9th International Anti-corruption Conference, Durban, South Africa, October (pp. 3-5).

Finansial.bisnis.com. (2020). Selain Maybank, ini kasus pembobolan dana nasabah Bank sepanjang 2020. (Online). https://finansial.bisnis.com/read/202 
01109/90/1315253/selain-maybankini-kasus-pembobolan-dana-nasabahbank-sepanjang-2020 diakses 11 November 2020.

Huntington S. P. (1968). Political Order in Changing Societies. New Haven: Yale University Press

Hukumonline.com (2020). Pentingnya digital forensic bagi korporasi. (Online).

https://www.hukumonline.com/berita /baca/lt5e54adff01699/pentingnyadigital-forensic-bagi-korporasi/ diakses 10 November 2020.

(2019). Ini peran akuntansi forensic dalam pembuktiaan fraud di pengadilan. (Online). hukumonline.com/berita/baca/lt5d28 3a23ea5a6/ini-peran-akuntansiforensik-dalam-pembuktian-ifraud-idi-pengadilan/ diakses 11 November 2020

Islam, M. J., Rahman, M. H., \& Hossan, M. T. (2011). Forensic accounting as a tool for detecting fraud and corruption: an empirical study in Bangladesh. ASA University Review, 5(2), 77-85.

Jppn.com. (2011). Audit forensic bakal ungkap skandal Century. (Online). https://www.jpnn.com/news/auditforensik-bakal-ungkap-skandalcentury diakses 11 November 2020

Karyono (2013). Forensic Fraud. Penerbit Andi Yogyakarta

Kompas.com. (2011). Audit bisa menjadi bukti awal. (Online). https://nasional.kompas.com/read/20 11/09/29/03211669/audit.bisa.menja di.bukti.awal diakses 11 November 2020

(2020). Soal usulan audit forensic kasus Jiwasraya Kejagung sebut sudah lakukan. (Online). https://nasional.kompas.com/read/20 20/01/20/22050031/soal-usulanaudit-forensik-kasus-jiwasrayakejagung-sebut-sudah- lakukan?page $=$ all
November 2020 diakses $\quad 11$ (2020). ICW ada 169 Kasus Korupsi sepanjang Semester 1 tahun 2020.

(Online).https://nasional.kompas.co $\mathrm{m} / \mathrm{read} / 2020 / 09 / 29 / 16112851 / \mathrm{icw}-$ ada-169-kasus-korupsi-sepanjangsemester-i-2020
November 2020. diakses 11

(2020). Kepala Cabang Maybank Cipulir Jadi Tersangka Raibnya Miliaran Rupiah Uang. (Online).

https://nasional.kompas.com/read/20 20/11/06/08584091/kepala-cabangmaybank-cipulir-jadi-tersangkaraibnya-miliaran-rupiah-uang, diakses 11 November 2020.

Lediastuti, V., \& Subandijo, U. (2014). Audit Forensik Terhadap Pengelolaan dan Pertanggungjawaban Keuangan Negara (Studi Kasus Pada Badan Pemeriksa Keuangan RI). Jurnal Magister Akuntansi Trisakti,1(1), 89-108.

Mamahit, A. I., \& Urumsah, D. (2018). The Comprehensive Model of Whistleblowing, Forensic Audit, Audit Investigation and Fraud Detection. Journal of Accounting and Strategic Finance, 1 (2), 153162.

Near, J. P., \& Miceli, M. P. (1995). Effective-whistle blowing. Academy of management review, 20(3), 679708 .

Nurharjanti, N. N. (2017). Faktor-Faktor yang Berhubungan dengan Fraud Pengadaan Barang/Jasa di Lembaga Publik. Jurnal Akuntansi dan Investasi, 18(2), 209-221.

Ocansey, E. O. N. D. (2017). Forensic accounting and the combating of economic and financial crimes in Ghana. European Scientific 
Okoye, E. I., \& Gbegi, D. O. (2013). Forensic accounting: A tool for fraud detection and prevention in the public sector.(A study of selected ministries in Kogi state). Okoye, EI \& Gbegi, DO (2013). Forensic Accounting: A Tool for Fraud Detection and Prevention in the Public Sector.(A Study of Selected Ministries in Kogi State). International Journal of Academic Research in Business and Social Sciences, 3(3), 1-19.

Okpako, A. E. P., \& Atube, E. N. (2013). The impact of forensic accounting on fraud detection. European Journal of Business and Management, 5(26), 61-70.

Prabowo, A. (2017). Keahlian Akuntan Forensik dan Pendidikan Akuntansi Forensik di Indonesia. Anti Corruption Clearing House. Universitas Tanri Abeng. Indonesia,(online).

Rahmayani, L., Kamaliah, dan Susilatri. (2014). Pengaruh Kemampuan Auditor, Skeptisisme Profesionalisme Auditor, Teknik Audit dan Whistleblower Terhadap Efektivitas Pelaksanaan Audit Investigasi Dalam Pengungkapan Kecurangan (Studi Empiris pada BPK dan BPKP Perwakilan Provinsi Riau). Jom Fekon, 1(2), 1-15.

Schacter, M., \& Shah, A. (2000, December). Anti-corruption Programs: Look Before You Leap. In Prepared for the International Conference on Corruption, Seoul, South Korea.

Syahputra, B. E., \& Urumsah, D. (2019). Deteksi Fraud Melalui Audit Pemeritnahan yang Efektif; Analisis Multi Grup Gender dan Pengalaman. Jurnal Akuntansi dan Bisnis, 19 (1), 31-42.

Semendawai, A.H., Santoso, F., Wagiman W., Omas, B., Susilaningtias, \&
Wiryawan, S., (2011). Memahami Whistleblower. Jakarta : LPSK

Temitope, OA (2014). Performance of Commercial Banks on Nigeria'. Research Journal of Finance and Accounting. Vol 5, No 8, pp 103-109 Tempo.co. (2020). Empat fakta dalam perkara korupsi bekas Menpora Imam Nahrawi. (Online). https://nasional.tempo.co/read/13594 05/empat-fakta-dalam-perkarakorupsi-bekas-menpora-imamnahrawi/full\&view=ok, diakses 11 November 2020.

Tuanakotta, T.M. (2010). Akuntansi Forensik dan Audit Investigatif (Edisi ke-2). Jakarta: Salemba Empat.

(2017). Akuntansi Forensik dan Audit Investigatif. Jakarta: Salemba Empat.

Wiratmaja, I. D.N. (2010). Akuntansi Forensik dalam Upaya Pemberantasan Tindak Pidana Korupsi. Jurnal Ilmiah Akuntansi dan Bisnis, 5 (2), 1-26.

Zed, M. (2004). Metode Penelitian Kepustakaan. Yayasan Obor Indonesia. 